\title{
Amphibia, Anura, Pipidae, Pipa carvalhoi (Miranda- Ribeiro, 1937): Distribution extension and geographic distribution map in the southeast of Brazil
}

\author{
Emanuel Teixeira da Silva ${ }^{1 *}$, Vitor Dias Fernandes ${ }^{1}$, Diego José Santana ${ }^{2}$ and Renato Neves Feio ${ }^{1}$ \\ 1 Universidade Federal de Viçosa, Departamento de Biologia Animal, Museu de Zoologia João Moojen. CEP 36570-000. Viçosa, MG, Brazil. \\ 2 Universidade Federal da Paraíba, Centro de Ciências Exatas e da Natureza, Departamento de Sistemática e Ecologia. CEP 58051-900. João Pessoa, \\ PB, Brazil. \\ * Corresponding author. Email: etsbio@yahoo.com.br
}

\begin{abstract}
We report new records for the Carvalho's Surinam Toad Pipa carvalhoi in state of Minas Gerais, southeast of Brazil, extending its occurrence in the southern portion of its known geographic range.
\end{abstract}

The genus Pipa currently encompasses seven species of aquatic frogs: P. arrabali Izecksohn, 1976, P. aspera Müller, 1924, P. carvalhoi (Miranda-Ribeiro, 1937), P. myersi Trueb, 1984, P. parva Ruthven and Gaige, 1923, P. pipa (Linnaeus, 1758 ) and $P$. snethlageae Müller, 1914. With the exception of $P$. carvalhoi, the distribution of other species is related to the Amazon and Orinoco rivers' basins, or to the south of Panama and northwestern Colombia (P. myersi) and the drainages of Maracaibo Lake in Venezuela (P. parva) (Trueb and Cannatella 1986; Frost 2010).

Pipa carvalhoi (Figure 1) is the unique species in the genus occurring in eastern Brazil, from the state of Ceará, southward to the state of Espírito Santo (Arzabe et al. 2008; Frost 2010). It occurs through the dry Caatinga and Atlantic Forest biomes, inhabiting permanent and temporary water bodies, as also streams and marshes, being more frequent in the little deep margins covered by vegetation (Carvalho 1937; 1939; Arzabe et al. 2008). Its reproduction takes place underwater and the eggs are carried on the back of the female (Trueb and Cannatella 1986; Arzabe et al. 2008). The tadpole's development also occurs in the water, as in P. myersi and P. parva (Carvalho 1939; Trueb and Cannatella 1986; Arzabe et al. 2008).

The finding of this species in the state of Pernambuco suggested a distribution restricted to Brazilian northeast (Miranda Ribeiro 1937a; b; Carvalho 1937; 1939), but a few years after its description, Myers and Carvalho (1945) reported the occurrence of $P$. carvalhoi in the municipality of Santa Teresa, state of Espírito Santo, extending the species' known distribution more than 1,500 km southward. Since then, the species has been reported north to states of Paraíba and Ceará (Arzabe 1999; Vieira et al. 2007; Arzabe et al. 2008; Frost 2010), and south to the municipality of Serra, Espírito Santo (Museu de Biologia Professor Mello Leitão 2010), as also in various localities along this gradient (Trueb and Cannatella 1986; Feio and Caramaschi 1995; Arzabe 1999; Silvano and Pimenta 2003; Canedo et al. 2006; Vieira et al. 2007; Arzabe et al.
2008). Herein we present data on the distribution of $P$. carvalhoi in the southeast of Brazil, as also new records in state of Minas Gerais, improving the knowledge about its geographic distribution.

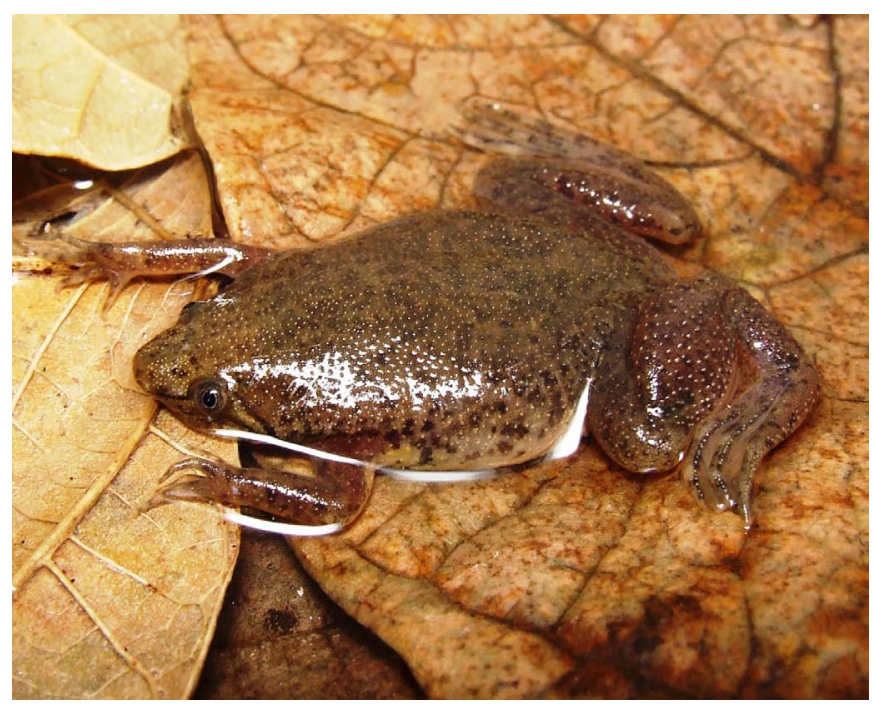

Figure 1. Pipa carvalhoi (MZUFV 8671, female, in life) from Sete Cachoeiras, municipality of Ferros, Minas Gerais. Photo by D. J. Santana.

Our map is based on literature records (Trueb and Canatella 1986; Feio and Caramaschi 1995; Arzabe et al. 2008) and on specimens housed at the scientific collections of Museu de Zoologia João Moojen, Universidade Federal de Viçosa, in Viçosa, Minas Gerais (MZUFV); Museu de Ciências Naturais, Pontifícia Universidade Católica de Minas Gerais (MCN-AM), and Universidade Federal de Minas Gerais (UFMG), both in Belo Horizonte, Minas Gerais; Coleção Herpetológica da Universidade de Brasília, in Brasília, Distrito Federal (CHUNB); Museu Nacional, in Rio de Janeiro, Rio de Janeiro (MNRJ); and Museu de Biologia Prof. Mello Leitão, Santa Tereza, Espírito Santo (MBML), this last one obtained from the SpeciesLink database (Museu de Biologia Professor Mello Leitão 2010). 
The evaluation of the records as new or not was based on the comparison with the distribution map proposed by Arzabe et al. (2008).

In Espírito Santo, the occurrence of $P$. carvalhoi is reported from the municipalities of São Gabriel da Palha (MBML 4852), Baixo Guandu (MBML 309-323), and Colatina (MBML 6206-6209), all these three localities in the Doce River basin, as well from municipalities of São João de Petrópolis (MNRJ 1943; 10401-10409), Santa Tereza (MBML 144-145; 308-309; 2559-2560; 45184519 and 4524) and Serra (MBML 146-153; 5502). In Minas Gerais, the occurrence of $P$. carvalhoi is reported from the Jequitinhonha River basin, in municipalities of Itinga (cited as "Santana, município Itaobim" by Trueb and Cannatella 1986), Araçuaí (Feio and Caramaschi 1995; CHUNB 42633, 42651-42671, 43494), Salto da Divisa (MCNAM 4868-4869, MZUFV 5451-5452) and Almenara (MZUFV 5450, 5397-5398); from the Mucuri River basin, in municipalities of Poté (MZUFV 6228-6230) and Carlos Chagas (MCNAM 11349); and from Doce River basin in municipalities of Resplendor (MZUFV 9947-9950) and Aimorés (MCNAM 1306-1307, 1508-1510, 1522-1525), near the boundary of Minas Gerais and Espírito Santo states (Figure 2).

On 20-21 March and 24-26 May 2008 we collected six specimens of P. carvalhoi (MZUFV 8441-8442, 8670-8671, and 8675-8676) in two aquatic environments near the locality of Sete Cachoeiras (19²1'58.69" S, 4254'08.68' W), municipality of Ferros, central region of Minas Gerais, in the Santo Antônio River basin, a tributary of Doce River (collection permits 079/2008 NUFAS/MG, process number 02015.013455/2007-36). The MZUFV collection also has two specimens (MZUFV 7731-7732) from the municipality of Governador Valadares, also in Doce River basin. In addition, the UFMG collection has three specimens from the municipality of Alvarenga (UFMG 2067-2069), located at Manhuaçu River basin, also a tributary of Doce River. These three localities are new records in state of Minas Gerais according to the data previously available (Trueb and Canatella 1986; Arzabe et al. 2008), the record of Ferros being the westernmost for the species, extending its distribution near to $150 \mathrm{~km}$ west in Doce River basin, from the locality of Aimorés (Figure 2).

Pipa carvalhoi is known to occupy relatively impacted environments, as also artificial ponds, in altitudes higher than 800 m (Miranda-Ribeiro 1937a; Carvalho 1937; 1939; Canedo et al. 2006; Arzabe et al. 2008), what indicates a broader distribution inland in southeastern Brazil, being possible to find this species in southern localities, as the high Doce River basin. Our record in Ferros municipality was made during an environmental impact assessment for hydroelectric dam projects, as well as the records in Aimorés, Alvarenga and Carlos Chagas municipalities. Despite the negative impacts these projects can promote on local faunas, the information obtained during the surveys required for their authorization are very useful on the improving of our knowledge about the geographic distribution of many Brazilian animal species.

ACKnowledgments: We are grateful to Centro de Estudos Ecológicos e Educação Ambiental for financial support during the surveys in municipality of Ferros; Lívia A. Coelho and Paulo S. Fiuza Ferreira for fieldwork assistance; Luciana B. Nascimento for allowing examination of specimens housed in MCNAM; J. P. Pombal Jr. for allowing examination of specimens housed in MNRJ; Marcela A. Brasil and Mariana C. M. Viana for allowing information of specimens housed in CHUNB; Patrícia S. Santos for allowing information of specimens housed in UFMG; Juliana Peres for confirming the localities of specimens housed at MBML; and Henrique C. Costa for suggestions on the first draft of the manuscript.

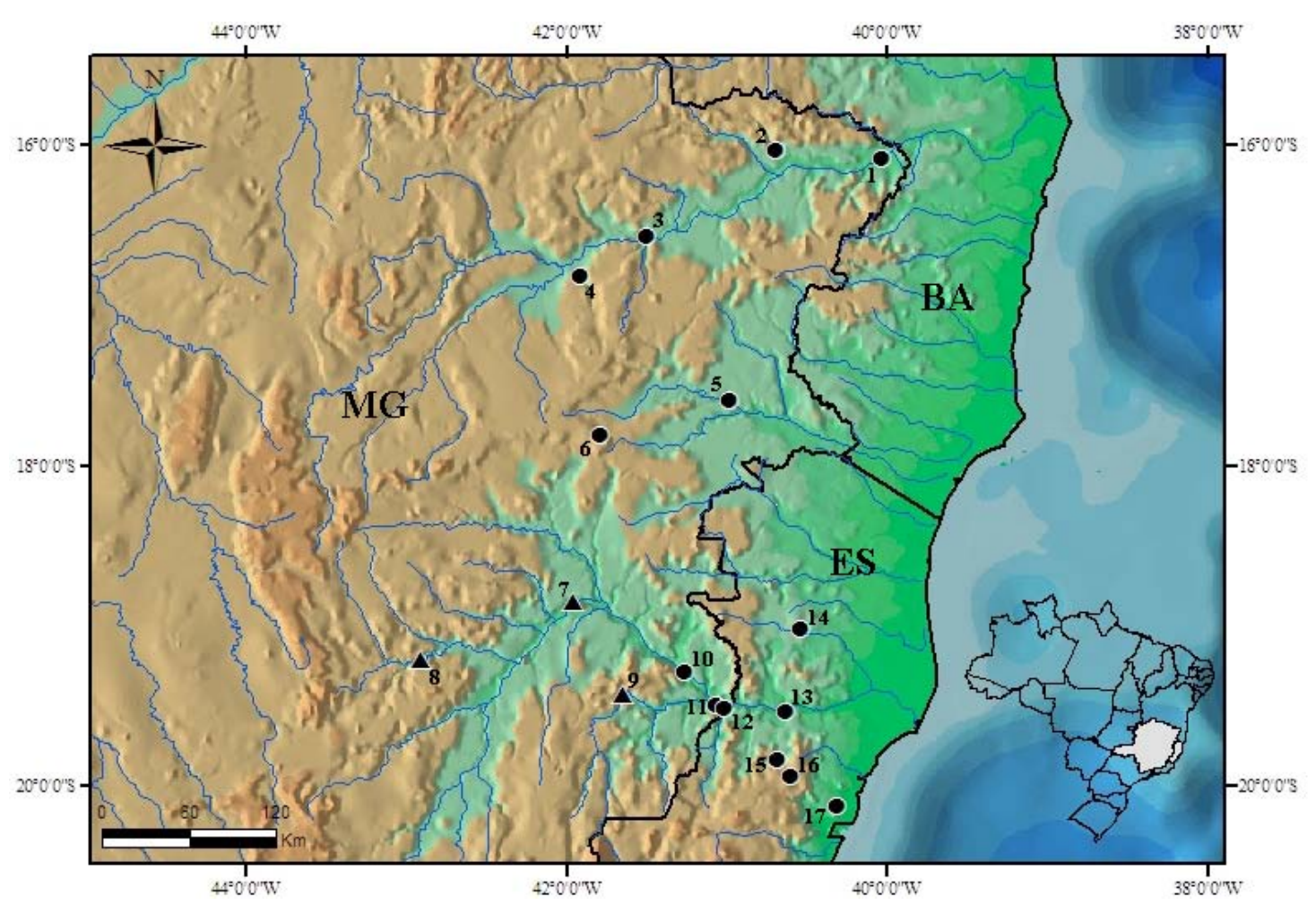

FIGURE 2. Records of Pipa carvalhoi in the southeast of Brazil. A map of the total distribution suggested for the species is provided by Arzabe et al. (2008). MINAS GERAIS (MG): 1- Salto da Divisa; 2- Almenara; 3- Itinga; 4- Araçuaí; 5- Carlos Chagas; 6- Poté; 7- Governador Valadares; 8- Ferros; 9Alvarenga; 10- Resplendor, 11- Aimorés. ESPÍRITO SANTO (ES): 12- Baixo Guandu; 13- Colatina; 14- São Gabriel da Palha; 15- São João de Petrópolis; 16- Santa Tereza; 17- Serra. New records are represented by triangles. 


\section{Literature Cited}

Arzabe, C. 1999. Reproductive activity patterns of anurans in two different altitudinal sites within the Brazilian Caatinga. Revista Brasileira de Zoologia 16(3): 851-864.

Arzabe, C., G. Skuk and M. Beier. 2008. Pipa carvalhoi. In IUCN 2010. IUCN Red List of Threatened Species. Version 2010.2. Electronic Database accessible at http//:www.iucnredlist.org/apps/redlist/ details/58160/0. Captured on 29 July 2010.

Canedo, C., J.P. Garcia, R. Fernandes, and J.P. Pombal Jr. 2006. Diet of Pipa carvalhoi (Amphibia, Pipidae) is not influenced by female parental care. Herpetological Review 37(1): 44-45.

Carvalho, A.L. 1937. Notas oecologicas e zoogeographicas sobre vertebrados do nordeste brasileiro. O Campo 1937(Mar): 12-15.

Carvalho, A.L. 1939. Notas sobre Hemipipa carvalhoi Mir.-Rib. (Batrachia Anura: Pipidae). 1ª parte. Boletim Biológico (Nova Série) 4(3): 394414.

Feio, R.N. and U. Caramaschi. 1995. Aspectos zoogeográficos dos anfíbios do médio rio Jequitinhonha, nordeste de Minas Gerais, Brasil. Revista Ceres 42(239): 53-61.

Frost, D. 2010. Amphibian Species of the World: an Online Reference. Version 5.4 (8 April 2010). Electronic Database accessible at http:// research.amnh.org/herpetology/amphibian. Captured on 29 July 2010.

Museu de Biologia Professor Mello Leitão 2010. Coleção de Anfíbios. Electronic database accessible at http://splink.cria.org.br. Captured on 29 July 2010.

Miranda-Ribeiro, A. 1937a. Sobre uma collecção de vertebrados do nordeste brasileiro. Primeira parte: peixes e batrachios. O Campo 1937(Jan.): 54-56.
Miranda-Ribeiro, A. 1937b. Ainda os batrachios do nordeste. O Campo 1937(Mar.): 26.

Myers, G.S. and A.L. Carvalho. 1945. Notes on some new or little known Brazilian amphibians, with an examination of the history of the Plata salamander, Ensatina platensis. Boletim do Museu Nacional do Rio de Janeiro, Nova Série Zoologia 35(Mai.): 1-24.

Silvano, D.L. and B.V.S. Pimenta. 2003. Diversidade e distribuição de anfíbios na Mata Atlântica do Sul da Bahia; p. 1-22 In P.I. Prado, E.C. Landau, R.T. Moura, L.P.S. Pinto, G.A.B. Fonseca and K. Alger (ed.) Corredor de Biodiversidade na Mata Atlântica do Sul da Bahia. Ilhéus: CD-ROM, IESB/CI/CABS/UFMG/UNICAMP.

Trueb, L. and D.C. Cannatella. 1986. Systematics, morphology, and phylogeny of genus Pipa (Anura: Pipidae). Herpetologica 42(4): 412449.

Vieira, W.L.S., C. Arzabe and G.G. Santana. 2007. Composição e distribuição espaço-temporal de anuros no Cariri paraibano, nordeste do Brasil. Oecologia Brasiliensis 11(3): 383-396.

RECEIVED: November 2009

REVISED: July 2010

ACCEPTED: August 2010

Published ONLINE: September 2010

EDITORIAL RESPONSIBILITY: Mara Cíntia Kiefer 